\title{
Flood of the Century
}

\author{
by Mary Boccaccio
}

$\mathbf{T}$ he immediate days and weeks following the descent of Hurricane Dennis, followed closely by Floyd, brought a series of difficult and traumatic experiences that many eastern North Carolinians will remember for a long time. The East Carolina University campus closed at 2 p.m. on Wednesday, September 15,1999 , and did not reopen until September 27 for faculty and staff and two days later for students. Both of the local television stations offered continual flood coverage, video clips, and interviews. Families lost homes and livelihoods, and 52 people lost their lives.

On September 28, Dr. Carroll Varner, Director of Joyner Library, suggested assembling a collection of flood-related materials. Documentation efforts have resulted in the Flood of the Century Collection. The collection has been made possible through a variety of technological advances, including e-mail, Web pages, the Internet, digital cameras, camcorders, and the like. There have been over 100 Web pages on the Internet about the effects of Floyd. The Library has a flood page <http:// www.lib.ecu.edu/SpclColl/ special.html> with photographs from the collection, a chronology, statistics, and links. Federal, state, and local agencies banded together to speed recovery, and these activities need to be documented also.

Currently, the collection has over 60 donations of a variety of types of materials. There are many color photographs - everything from the bandshell on the town common

underwater to flooded student apartments on the edge of campus to photos of the Missouri Baptist Convention Disaster Group setting up cooking tents in the parking lot of Memorial Baptist Church to provide meals for victims and relief workers. Pieces of the collection are starting to come together now, like a jigsaw puzzle. Accompanying the photos of the MBC Disaster Group is an oral interview with the group's leader after four weeks on site, just before they packed up to leave. The Blue Cap (group leader) discusses the group's organization, daily activities, and interfaces with local and national groups. Now the pictures have a voice.

The Library used the campus email network to announce the project, and staff and faculty from many departments responded with suggestions. One suggestion in particular surprised me. Education, Sociology, and Psychology faculty all suggested interviewing children, who frequently are left out. They were right. Children historically are not well documented in manuscript collections and this was a chance for an additional perspective.

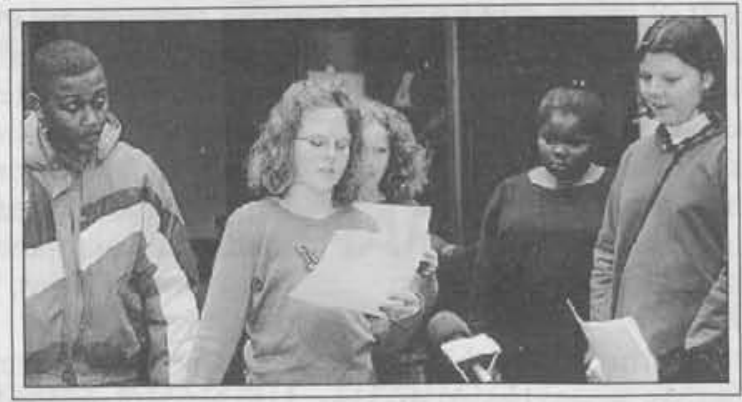

essays her class was writing. Of course we were. The youngsters worked on the essays for several months. Sarah Mitchelson and I brought them to the Library to present their essays to the Associate Director and for refreshments. We invited the local television stations and press so it became an event for them. They were on the local news the morning paper printed pictures of them reading their essays. Subsequently the essays were loaded on the FEMA for Kids Web page <http:/ /www.fema.gov/Kids/k2k.htm>. They have been used by AP and UPI, and have been in the "Winners" section of the Southeastern edition of the Wall Street Journal.

Recently, we acquired a video from a young man in Pitt County who took a camcorder in a boat in that area on three separate occasions. We still have material coming in. People send printed materials. 1 have a long list of people involved in the flood in one way or another who have agreed to do an interview. Buyouts are still continuing, and recovery and repairs will go on for quite a while. There was a conference about the flood and environmental disasters, "Recovery in the Coastal Plain," sponsored by the Geography Department at East Carolina University. People from a variety of fields participated. Each field has its own type of recovery work to perform. For our Flood of the Century Collection there are many more interviews to get, and more

One local fifth grade teacher called and asked if we were interested in the photographs, videos, and written information to find and preserve. 